\title{
Over kennissystemen, organisaties en wishful thinking
}

\author{
Drs. J. G. J. M. Benders en \\ Drs. F. L. J. W. Manders
}

\section{Inleiding}

Ondanks het feit, dat kennissystemen al meer dan 15 jaar in ontwikkeling zijn, kunnen zij nog steeds als een nieuwe technologie beschouwd worden. De feitelijke toepassing ervan staat nog in de kinderschoenen.

Bij het invoeren van nieuwe technologieën in arbeidsorganisaties vinden vaak wijzigingen plaats in de verdeling van taken, verantwoordelijkheden en bevoegdheden over werknemers. Deze wijzigingen worden soms als een logisch uitvloeisel van de invoering van een nieuwe technologie gezien, waarbij men niet of nauwelijks stil staat. Automatisering wordt in dat geval als een technisch probleem gezien, dat in de praktijk wordt gedelegeerd naar technici en automatiseringsdeskundigen (Koopman-Iwema, 1986). Met name technici lijken bezield te zijn door een heilig vertrouwen in de techniek. In hun visie is het vervangen van falende mensen door perfect functionerende technische systemen de oplossing voor veel problemen. Ook Van de Poel geeft blijk van een dergelijk vertrouwen in de techniek. Hij stelt, dat beheersing in organisaties problematisch blijft, 'omdat de menselijke factor nog altijd niet geheel vervangen is door machines' $(1989,151)$.

Deze technocratische visie gaat er blijkbaar vanuit, dat de technische systemen op een zodanige manier worden gebruikt, dat het beoogde resultaat ook bereikt wordt. Aan de organisatorische inbedding van de techniek hoeft geen of slechts weinig aandacht te worden besteed. Blijkens het technische karakter van de meeste publikaties over kennis- en expertsystemen lijkt dit euvel ook bij deze nieuwe vormen van techniek voor te komen. Gelukkig zijn er recentelijk enige publikaties verschenen, waarin aandacht wordt gevraagd voor organisatorische aspecten van kennissystemen (zie bijvoorbeeld Ryan, 1988; Hartman, 1990; Van den Besselaar, 1989; Van Steenis, 1990). Dit is ook geen overbodige luxe nu de grotere Nederlandse ondernemingen langzamerhand interesse beginnen te tonen voor kennissystemen en op langere termijn de diffusie van deze technologie naar het midden- en kleinbedrijf te verwachten is.

In het onderhavige artikel wordt getracht om op basis van een aantal in de literatuur bekende en in de praktijk werkende kennissystemen een aantal kanttekeningen te plaatsen bij het gebruik van deze systemen. Het artikel beoogt om de organisatorische problematiek rond kennissystemen duidelijk te maken en te systematiseren. Hieruit kan lering worden getrokken om te komen tot een ontwerp gerichte benadering van kennissystemen, waarbij organisatorische aspecten nadrukkelijk worden meegenomen.

De opbouw van dit artikel is als volgt. In paragraaf twee wordt uiteengezet wat onder kennis- en expertsystemen wordt verstaan en wanneer ze gebruikt (kunnen) worden. In paragraaf drie staat

Drs. J. G. J. M. Benders is als AlO verbonden aan de sectie Organisatie van de vakgroep Bedrijfseconomie van de Faculteit der Economische Wetenschappen van de Katholieke Universiteit Brabant.

Drs. F. L. J. W. Manders is als universitair docent verbonden aan de vakgroep Personeelwetenschappen van de Faculteit der Sociale Wetenschappen van de Katholieke Universiteit Brabant. 


\section{MAB}

de invloed van kennissystemen op de besluitvorming binnen organisaties centraal. Paragraaf vier beschrijft verschillende soorten kennissystemen vanuit de rol die deze systemen vervullen bij de besluitvorming. Het artikel wordt besloten met enkele conclusies in de vijfde en laatste paragraaf.

\section{Kennis- en expertsystemen}

Een kennissysteem kan gedefinieerd worden als een computersysteem dat gebruik maakt van formele kennis voor het trekken van conclusies en het geven van adviezen of diagnoses (Wester, 1989, 4).

Een expertsysteem is een computersysteem dat de kennis van een menselijke deskundige, een expert dus, gebruikt en op basis van deze kennis conclusies trekt of adviezen geeft over een bepaald toepassingsgebied (zie onder andere Pruijm, 1986, 131; Manders 1990a, 202; Terplan, $1987,1)$. Een expertsysteem kan zodoende beschouwd worden als een kennissysteem waarbij de vastgelegde kennis van een expert afkomstig moet zijn.

Vaak worden deze twee termen door elkaar gebruikt en is de scheiding zoals die in de beide definities gemaakt wordt niet altijd in de literatuur terug te vinden; het onderscheid is gradueel. Volgens Wester $(1989,5)$ spreekt men tegenwoordig liever van kennissystemen dan van expertsystemen. Deze term sluit beter aan bij de Angelsaksische term Knowledge-Based Systems. Hij zegt hieromtrent onder meer: 'De term kennissystemen geeft beter aan waar het om gaat: om het expliciet vastleggen en gebruiken van kennis met computers.' (1989, 5). Deze kennis, afkomstig van menselijke deskundigen, wordt door gespecialiseerde bouwers met behulp van zogenaamde 'kennisacquisitie'-technieken omgezet in software.

Gezien de algemeen heersende verwarring rond de exacte inhoud van de termen kennis- en expertsystemen wordt in het vervolg van dit artikel de term kennissystemen gebruikt.

Een kennissysteem bestaat in het algemeen uit de volgende elementen (Lee, 1988, 88; Wester, 1989, 6):
1 kennisbank: hierin is de kennis van éen of meerdere personen vastgelegd (meestal in de vorm van regels (als $<$ conditie $>$ dan $<$ conclusie $>$ )). Daarnaast bevat de kennisbank (objectieve) feiten;

2 inferentiemechanisme; dit is een speciaal computerprogramma dat problemen oplost door interpretaties te maken c.q. conclusies te trekken op basis van de in de kennisbank weergegeven regels en feiten en in het werkgeheugen opgeslagen gegevens;

3 werkgeheugen: in het werkgeheugen worden de gegevens van het onderhanden zijnde geval opgeslagen.

Het systeem kan hierop terugvallen bij het oplossen van problemen. Ook kan hier de koppeling gelegd worden met andere informatiesystemen of andere kennissystemen, die reeds over gegevens omtrent het probleem beschikken;

4 uitlegfunctie: evenals menselijke experts moet een kennissysteem desgevraagd uitleg kunnen geven over: waarom een bepaalde vraag gesteld wordt, wat de antwoordmogelijkheden zijn of hoe het systeem tot een bepaald oordeel gekomen is.

In het algemeen wordt dit als één van de voordelen van kennissystemen boven conventionele programmatuur beschouwd;

5 systeem-gebruiker communicatie of interface: de interface vormt de zichtbare buitenkant van een kennissysteem. Het gaat hier om de communicatie tussen de gebruikers en het systeem. Vaak vindt deze communicatie plaats in de vorm van een dialoog (vraag en antwoord), waarbij gebruik kan worden gemaakt van menu's.

In figuur 1 zijn de relaties tussen deze componenten onderling en de gebruiker weergegeven.

Om aan te geven hoe het inferentiemechanisme kan werken volgt nu een simpel voorbeeld.

Stel dat de volgende uitspraken omtrent een bepaald onderwerp waar zijn:

a Alle mannen zijn langer dan 1 meter en 80 centimeter.

b Jan is een man. 


\section{MAB}

Figuur 1: De architectuur van een kennissysteem

Ander informatiesysteem of kennissysteem

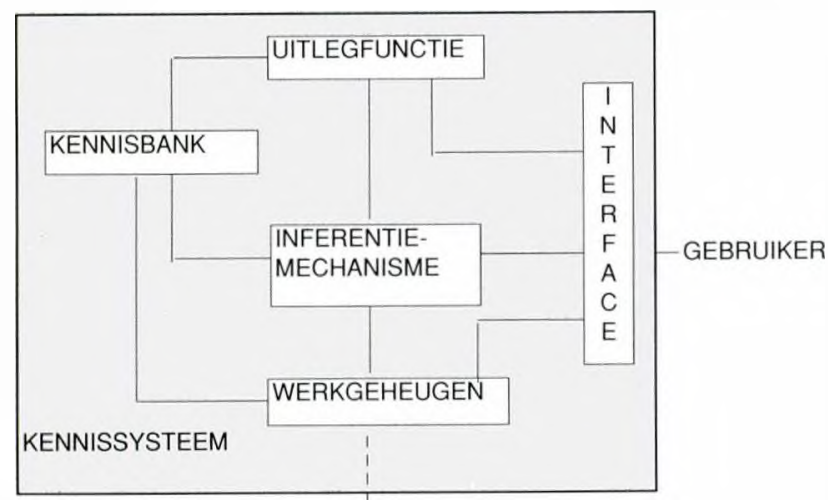

Ander informatiesysteem of kennissysteem

Ondanks dat $\mathrm{u}$ Jan niet kent kunt $\mathrm{u}$ uit deze uitspraken de conclusie trekken:

c Jan is langer dan 1 meter en 80 centimeter.

De toepassingsgebieden van kennissystemen zijn divers, maar liggen vooral op de terreinen van diagnose, planning en ontwerp, besturing en regelgeving. De in de literatuur genoemde toepassingen betreffen voornamelijk operationele besluitvorming. Dit in tegenstelling tot de 'decision support systems' systemen, die ook op tactische en strategische besluitvormingsniveaus ingezet worden. Figuur 2 geeft deze inzetbaarheid van de onderscheiden systemen schematisch weer.

Over het algemeen kan men stellen, dat de mate van gestructureerdheid van de beslissing afneemt als het besluitvormingsniveau stijgt. Kennissystemen kunnen voor een organisatie aantrekkelijk zijn als menselijke experts schaars zijn, bijvoorbeeld bij een hoge vraag naar dergelijke experts, als experts moeilijk op te leiden zijn en/of als er sprake is van een definieerbaar en tevens oplosbaar probleem dat bovendien complex van aard is (Keus, 1987, 23; Hertz, 1988, 4849; Terplan, 1987, 2). Dit laatste heeft weer te maken met de mate, waarin een probleem gestructureerd is. Voor ongestructureerde of niet te structureren problemen zijn niet of slechts zeer moeilijk kennissystemen te ontwikkelen. Daarentegen zijn gestructureerde problemen met conventionele programmatuur eenvoudig te modelleren. Resteren de semi-gestructureerde problemen waarvoor kennissystemen gebouwd kunnen worden (Manders, 1990b, 36). De operationele besluitvormingsprocessen, waarvoor kennissystemen worden ingezet, zijn dus slechts zelden werkelijk gestructureerd. Het onderbrengen van een dergelijk besluitvormingsproces in een kennissysteem vereist in feite een structurering en formalisering van de kennis van een menselijke deskundige.

Figuur 2: Niveaus van besluitvorming en soorten informatiesystemen



Kennissystemen worden dus toegepast om het menselijk denken te simuleren of zelfs geheel te vervangen. Ze simuleren of vervangen daarmee het nemen van bepaalde besluiten binnen een organisatie. Maar waarin zit de winst van de toepassing van kennissystemen als deze toch niet meer zijn dan op computergeheugen vastgelegde menselijke kennis en ervaring op een bepaald gebied? En als er al voordelen zijn te behalen met kennissystemen, moet dan niet kritisch worden bekeken of deze voordelen wel zo groot zijn als vaak wordt voorgespiegeld? 


\section{MAB}

Een van de eerste en tevens moeilijkste stappen bij het ontwerpen van kennissystemen is het onttrekken van kennis aan experts op een bepaald gebied. De moeilijkheid hiervan is, dat de experts vaak slechts gedeeltelijk in staat zijn om duidelijk te maken op grond van welke factoren en volgens welke procedures ze beslissingen nemen. Experts blijken vaak op basis van intuïtieve redeneringen beslissingen te nemen. ${ }^{1}$ In een kennissysteem wordt een dergelijk besluitvormingsproces geëxpliciteerd door het vast te leggen in vastomlijnde procedures en besluitregels. Hayes (1989) noemt verschillende nadelen van een menselijke expert, die met een kennissysteem kunnen worden voorkomen: mensen worden moe, zijn niet altijd consistent en hebben emoties die kunnen meespelen bij de besluitvorming. Behalve deze cognitieve tekortkomingen van veelal tijdelijke aard noemt Hayes als verdere nadelen van menselijke experts, dat ze duur zijn en dat ze de organisatie kunnen verlaten, waarmee voor de organisatie relevante kennis verloren kan gaan. Kennissystemen ondervangen deze nadelen van menselijke deskundigen. Bovendien kan de bredere beschikbaarheid van kennis in de organisatie als een additioneel voordeel genoemd worden. Een leek kan door een kennissysteem te gebruiken toch beslissingen nemen op een veld waarop hij niet of minder deskundig is. De hiervoor benodigde kennis is immers niet meer uitsluitend aan één of meerdere experts voorbehouden, maar staat ook ter beschikking aan de gebruikers van kennissystemen.

Al deze voordelen van het gebruik van kennissystemen zijn uiteraard relevant, maar ze moeten wel gerelativeerd worden. Zoals zal worden betoogd in het onderstaande is het in veel gevallen nog maar de vraag of het doel van deze systemen, wellicht het beste te omschrijven als 'meer mensen in operationele processen besluiten laten nemen, die van een minstens gelijkwaardig kwalitatief niveau zijn als besluiten van (schaars beschikbare) experts', wel zo gemakkelijk gehaald kan worden.

\section{Betere bes/uitvorming}

Inderdaad kunnen kennissystemen een aantal menselijke tekortkomingen ondervangen. Emoti- onele factoren worden uitgeschakeld en het is mogelijk, dat er een grotere consistentie in de besluitvorming tot stand komt. Maar doordat kennissystemen gebaseerd zijn op de kennis van menselijke deskundigen ontstaat er een aantal problemen.

Het Latijnse spreekwoord 'Errare humanum est' (voor de niet-Latinisten: 'Vergissen is menselijk') gaat ook op voor experts. Hoewel een expert pas met recht een expert mag worden genoemd wanneer hij over aanzienlijk meer en diepere kennis beschikt dan leken, kan niet verwacht worden, dat experts nooit tot een foutieve conclusie komen. Fox $(1990,13)$ noemt de stelling 'Expertsystemen maken geen fouten' zelfs een mythe: mensen maken fouten en er bestaan grenzen aan menselijke kennis. Zeker wanneer het intuïtieve denken van menselijke experts is overgebracht in een kennissysteem, is het bovendien moeilijk te overzien of deze geëxpliciteerde intuitie tot foute beslissingen leidt of niet. Nu kunnen fouten in het ontwerp van kennissystemen gereduceerd (niet geëlimineerd) worden door de kennis van meerdere experts in het kennissysteem in te brengen. Dat dit gevolgen heeft voor de ontwikkelingskosten moge duidelijk zijn.

Er kunnen nog meer kanttekeningen worden gezet bij de kwaliteit van de besluitvorming. Een belangrijke en algemeen erkende beperking van kennissystemen is, dat ze slechts op een beperkt gebied, aangeduid met 'kennisdomein', inzetbaar zijn (Hayes, 1989). Met name aan de grenzen van dit kennisdomein wordt de kwaliteit van de door een kennissysteem aanbevolen of genomen beslissingen dubieus. Engelenburg (1990) illustreert dit punt op een amusante manier: de antwoorden die Engelenburg als gebruiker van het systeem geeft op de vragen van het systeem passen niet in de standaardset van antwoorden die het systeem verwacht, waardoor het door Engelenburg gewenste uiteindelijke antwoord niet bruikbaar is.

Een verdere complicatie ontstaat wanneer er veranderingen optreden in de voor het nemen van een beslissing relevante informatie. Een kennissysteem kan dan ook veel onderhoud vergen. 


\section{MAB}

Onderhoud is en blijft arbeidsintensief en dus duur. Van Steenis $(1990,43)$ zegt hierover: 'Men verwacht dat de onderhoudskosten van kennissystemen nog groter zullen zijn dan die van informatiesystemen, dus meer dan de daar gebruikelijke 70 procent van de totale kosten'. Deze hoge onderhoudskosten zouden de te verwachten besparingen op menselijk personeel wel eens aanzienlijk kunnen drukken.

Een volgend probleem vormt het zogenaamde GIGO-effect, 'Garbage In, Garbage Out'. Met GIGO wordt bedoeld, dat de kwaliteit van de in een systeem ingevoerde gegevens bepalend is voor de kwaliteit van output van dat systeem, in het onderhavige geval dus van de kwaliteit van de te nemen beslissing c.q. van het te geven advies. De invoer van de gegevens kan verstoord raken door bijvoorbeeld technische deficiënties, maar kan ook bewust door de gebruiker van het systeem gemanipuleerd worden. Een mooie illustratie van deze laatste factor wordt gegeven door Noë (1990). Het betreft een kennissysteem voor het beoordelen van uitkeringsaanvragen. 'De maatschappelijk werker stelt de vraag of de aanvrager samenwoont. Aanvankelijk is het antwoord volmondig 'Ja'. De maatschappelijk werker kijkt daarop fronsend en vraagt of hij dat wel zeker weet. De toon doet al vermoeden dat het gewenste antwoord eigenlijk 'Nee' moet zijn. De aanvrager zegt dan ook prompt: 'Nou, eigenlijk... Nee' (Noë, 1990, 2). Wanneer de gebruiker van een kennissysteem een bepaalde uitkomst wenst, kan hij deze bereiken door de invoer van de gegevens te manipuleren.

De stelling, dat door het gebruik van kennissystemen de 'bias' in de besluitvorming wordt weggenomen getuigt gezien het bovenstaande van enige naïveteit. Wellicht hebben ontwerpers van kennissystemen de eliminatie van 'bias' voor ogen, maar zolang de gebruiker de uiteindelijke beslissing neemt (wat in de meeste gevallen wenselijk is), is een dergelijk doel 'wishful thinking', zeker wanneer de gebruiker persoonlijke belangen bij een beslissing heeft. Dit is goed denkbaar bij bijvoorbeeld kredietverlening (Hayes, 1989) en personeelsselectie (Humpert e.a., 1989). Het ken- nissysteem kan in dergelijke gevallen voor de gebruiker zelfs een legitimerende functie vervullen: mensen hebben 'de neiging om van een geautomatiseerd systeem veel betere prestaties te verwachten dan van een menselijke expert' (Hartman, 1990, 150). Een dergelijk hoog verwachtingsniveau wordt zelfs door automatiseerders geschapen, maar kan door de gebruiker aangewend worden om voor de gebruiker wenselijke maar onjuiste beslissingen te legitimeren door te verwijzen naar het feit, dat het kennissysteem dit advies gaf. Een blindelings vertrouwen op de techniek zou in dergelijke gevallen wel eens averechts kunnen uitpakken.

Het beschikbaar zijn van een uitlegfaciliteit, die steevast genoemd wordt als een essentieel onderdeel van kennissystemen, is niet per se de oplossing voor een blind vertrouwen in het systeem. Zahedi (1987) verwacht van de uitlegfaciliteit zelfs een constante educatie van de gebruiker door het kennissysteem. Echter, het feit dat deze uitlegfaciliteit de gebruiker ter beschikking staat zegt nog niets over het daadwerkelijke gebruik ervan. Dat kost tijd; tijd, die strikt genomen niet produktief wordt aangewend. Met name in operationele besluitvormingsprocessen bestaat vaak een produktiedruk, die het gebruik van een uitlegfaciliteit niet bevordert. Wanneer de leek-gebruiker bovendien op zijn produktiviteit beoordeeld wordt, zal dit effect nog eens versterkt worden.

\section{Bredere beschikbaarheid van kennis}

Een belangrijk argument om kennissystemen in te zetten is de bredere beschikbaarheid van schaars aanwezige kennis in een organisatie. Doordat het kennissysteem deze kennis bevat, zijn ook minder deskundigen in staat om bepaalde, vaak routinematige beslissingen te nemen en heeft de eigenlijke expert zijn handen vrij voor het meer interessante werk, zo luiden twee argumenten. Eén van de doelen van het inzetten van kennissystemen is volgens Zahedi (1987) om de vaardigheid van medewerkers op het niveau van een kenner/expert te brengen. Met behulp van een kennissysteem kan iedere willekeurige medewerker functioneren als een expert, zo wordt wel gedacht. Het lage kennisniveau van de gebruiker 


\section{MAB}

wordt in deze gedachtengang blijkbaar gecompenseerd door de kennis van het kennissysteem. In principe zijn er hierdoor meer 'deskundigen', zoals de gebruikers van kennissystemen wel beschouwd worden, beschikbaar. 'Meer deskundigen' kan echter op gespannen voet staan met het vorige punt 'Betere besluitvorming'.

Immers, wanneer er veel besluiten moeten worden genomen op de rand van het kennisdomein en/of wanneer de relevante kennis snel veroudert, blijft een bepaalde mate van kennis bij de gebruiker noodzakelijk. Op straffe van foutieve en kostbare beslissingen mag het kennisniveau van de gebruiker niet zonder meer laag zijn en is dus toch slechts een beperkt aantal mensen beschikbaar. Een laag kennisniveau van de gebruiker is alleen mogelijk, wanneer het kennissysteem een volledig in kaart gebracht gebied bestrijkt, waarbinnen niet of nauwelijks veranderingen optreden. Maar op vele terreinen bijvoorbeeld bij kredietverlening en het stellen van medische diagnoses blijft een kritisch oordeel van de gebruiker over het door een kennissysteem gegeven advies noodzakelijk. De gebruiker van dergelijke systemen moet een kenner op zijn gebied zijn en blijven.

Er bestaat echter het gevaar, dat de kennis van de expert-gebruiker door het gebruik van het systeem erodeert. Net zoals het vermogen tot hoofdrekenen van gebruikers van rekenmachines door dit gebruik aanzienlijk lijkt achteruit te gaan, is voorstelbaar dat de kennis van gebruikers van kennissystemen achteruitgaat.

Van den Besselaar verwijst naar Karlsen en Oppen (1985), die op basis van een case-study concludeerden, dat eerder verworven kennis en vaardigheden verloren gaan wanneer iemand bepaalde werkzaamheden lange tijd niet verricht heeft. Verder verwijst hij naar Goeranzon en Josefson (1987), die constateerden, dat nieuw aangenomen taxateurs, die opgeleid waren met behulp van een kennissysteem, hun kennis gingen aanpassen aan die van het systeem. Blijkbaar gaan mensen bij een langdurig gebruik in toenemende mate vertrouwen op de door het systeem gegeven adviezen. Het gevaar van een 'mechanisch denkwerk' van de gebruiker (Van Steenis, 1990 ) is niet denkbeeldig.
Tenslotte is er het punt van het systeemonderhoud. Als er veranderingen optreden in het kennisdomein en de menselijke expert, wiens kennis betreffende het kennisdomein in het kennissysteem is ondergebracht, wie is dan nog in staat om veranderingen in het kennisdomein aan te brengen? Het onderhoud van het systeem staat en valt dan met de beschikbaarheid van een menselijke expert. Zo beschikte de ingenieur Kelly, die kort voor zijn pensioen stond, als enige over kennis met betrekking tot het onderhoud van de kolossale Vermilion-dam in Zuid-Californië (Rose, 1988). Aangezien hij de organisatie op korte termijn zou verlaten om met pensioen te gaan, werd besloten tot de bouw van een kennissysteem. Rose laat zich echter niet uit over het onderhoud van het kennissysteem zelf: wie moet dat gaan doen als de kennis van het systeem veroudert en Kelly weg is? Zeker in Californië, waar aardbevingen kunnen leiden tot wijzigingen in de geologische structuur, is dit méér dan een academische vraag.

\section{Soorten kennissystemen}

In het bovenstaande is gewezen op diverse organisatorische consequenties, waarvan men zich bij de invoering van kennissystemen wellicht niet altijd bewust is. De conclusie, dat men de invoering van kennissystemen dan maar beter achterwege kan laten, zou echter te ver gaan: het kind zou met het badwater worden weggegooid. Beter kan men trachten om de verdeling van taken, bevoegdheden en verantwoordelijkheden tussen mens en machine af te stemmen op het soort kennissysteem. De technische oplossing alleen volstaat dus niet, maar moet aangevuld worden met organisatorische maatregelen. In het onderstaande wordt op basis van een indeling van kennissystemen uiteengezet hoe taken, bevoegdheden en verantwoordelijkheden tussen mens en machine verdeeld zouden kunnen worden.

Manders (1990b, 36-38) geeft de volgende vier gebruiksmogelijkheden ('modes') van kennissystemen:

1 probleemoplosser, waarbij het kennissysteem de oplossing aandraagt; 
2 assistent;

3 verstrekker van een 'second opinion' over een bepaald probleem;

4 tutor bij het inzetten van een kenissysteem voor educatieve doeleinden.

De laatste toepassing zal in het vervolg van dit artikel buiten beschouwing blijven, aangezien in dit geval het kennissysteem niet ter ondersteuning van beslissingen gebruikt wordt.

Kennissystemen kunnen worden ingedeeld naar mate van deskundigheid die bij de gebruiker vereist is om tot kwalitatief goede beslissingen te kunnen komen. Wanneer de deskundigheid van de gebruiker laag is, moet deze geheel op het systeem kunnen vertrouwen om tot een goede beslissing te kunnen komen. Het in het kennissysteem opgenomen beslissingsproces moet dan ook:

a het onderhavige probleemgebied volledig beschrijven en;

b up-to-date zijn.

Met een 'volledige beschrijving van het onderhavige probleemgebied' wordt bedoeld, dat ook op de grenzen van het kennisdomein geen fouten worden gemaakt. Zoals al gezegd, kunnen zich met name op de grenzen van het kennisdomein problemen voordoen met de kwaliteit van de beslissingen. Wanneer het kennissysteem eigenlijk geen oordeel kan geven bij gebrek aan kennis, dan moet dit expliciet gemeld worden.

Dit geldt ook voor de mate van zekerheid waarmee bepaalde conclusies getrokken worden. Wanneer de mate van zekerheid kleiner is dan 100 percent, blijft een bepaald kennisniveau van de gebruiker noodzakelijk.

Met 'up-to-date zijn' wordt bedoeld, dat de door het kennissysteem genomen beslissing (c.q. het gegeven advies) conform de op dat moment geldende situatie en regels is. Wanneer het probleemgebied niet stabiel is, zal het kennissysteem voortdurend en onmiddellijk moeten worden aangepast aan de nieuwe situatie. Wanneer de onderhoudskosten hierdoor inderdaad fors oplopen, rijst de vraag of de kostenbesparingen op experts opwegen tegen de kostentoename van het onderhoud.
Slechts wanneer aan beide genoemde voorwaarden is voldaan kan een kennissysteem als oplosser van een probleem worden ingezet en kunnen leken als gebruiker worden ingezet (ook bij het gebruik als tutor mag men aannemen dat aan beide voorwaarden is voldaan). In alle andere gevallen blijft een bepaald kennisniveau van de gebruiker vereist. Kortom, de mate waarin een kennissysteem een bepaald probleemgebied ook daadwerkelijk volledig kan overzien, is van invloed op het vereiste deskundigheidsniveau van de gebruiker. Problemen kunnen zich voordoen wanneer het aanwezige deskundigheidsniveau niet overeenkomt met vereiste c.q. gewenste deskundigheidsniveau.

Figuur 3: Toepasbaarheid en toepassing van kennissystemen

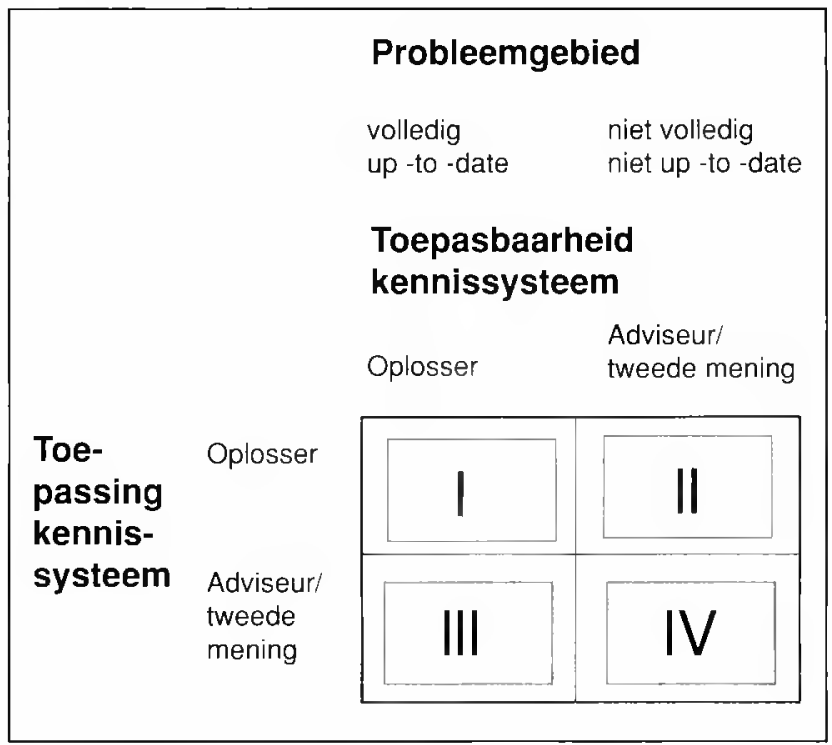

Figuur 3 beschrijft de toepasbaarheid en toepassing van kennissystemen.

Op de horizontale as staat de toepasbaarheid van kennissystemen. Zoals betoogd zijn deze slechts dan als oplossers inzetbaar, wanneer het probleemgebied volledig in kaart is gebracht én het kennissysteem onderhouden is (kwadrant I). Dit zal zelden het geval zijn: in het leeuwedeel der gevallen kan een kennissysteem alleen in zijn adviesfunctie gebruikt worden (kwadrant IV). De toepasbaarheid staat echter soms op gespannen 


\section{MAB}

voet met de daadwerkelijke toepassing. In de kwadranten II en III is er sprake van een verkeerd gebruik van kennissystemen.

In kwadrant III kan het kennissysteem gebruikt worden als oplosser, maar wordt gebruikt als adviseur. Hoewel het deskundigheidsniveau van de gebruiker laag kan zijn gezien het hoge probleemoplossend vermogen van het systeem, is dit niet het geval. Veel zal dit niet voorkomen, aangezien het vervangen van dure en schaarse experts door goedkope en ruimer beschikbare leken juist een reden voor toepassing van kennissystemen is. In kwadrant III laat een organisatie dan ook winstkansen liggen.

Kwadrant II lijkt echter wel op vrij grote schaal voor te komen: alle in de vorige paragraaf genoemde potentiële nadelen kunnen worden ondergebracht in dit kwadrant. Hoewel de conclusies van een in dit kwadrant in te delen kennissysteem eigenlijk slechts adviezen kunnen zijn, worden ze de facto als besluiten opgevat. Het lage deskundigheidsniveau van de gebruiker leidt weliswaar tot lage loonkosten, maar ook tot potentieel foute beslissingen met alle gevolgen van dien. Het lage deskundigheidsniveau van de gebruiker kan veroorzaakt zijn door zijn lage vooropleiding, maar ook door het optreden van kenniserosie. Aangezien echter niet bekend is of het kennissysteem wel de juiste beslissing neemt, kan de gebruiker niet zonder meer afgaan op de gegeven conclusie en moet hij in staat zijn om zijn eigen oordeel over het onderhavige probleem te kunnen geven op basis van zijn eigen deskundigheid.

Dit hoeft niet per se te betekenen, dat hij het zelf oplost, maar wel dat hij weet wanneer het probleem niet oplosbaar is met behulp van het kennissysteem en of het probleem dan doorverwezen moet worden naar een menselijke deskundige. De aansprakelijkheidsvraag komt hier naar voren: wie is verantwoordelijk voor een beslissing, die door een gebruiker van een kennissysteem genomen is op basis van een door dat kennissysteem getrokken, maar foutieve conclusie? Het antwoord op de laatste vraag zal praktisch altijd luiden: 'de gebruiker'. De vraag rijst dan echter, of de 'schuldige' redelijkerwijs wel anders had kunnen handelen: zou een dergelijke gebrui- ker gezien zijn deskundigheidsniveau van de betreffende materie en eventueel de prestatiedruk (produktiviteitseis in de vorm van aantal beslissingen per tijdseenheid) redelijkerwijs een foutieve beslissing hebben kunnen voorkomen óf had het meer voor de hand gelegen om door middel van organisatorische maatregelen (de gevolgen van) het voorkomen van foutieve beslissingen tegen te gaan? Of moet de bouwer van het kennissysteem verantwoordelijk worden gesteld? Maar de bouwer is bij de bouw van het systeem afhankelijk van de deskundige, die bereid is zijn kennis ter beschikking te stellen. Het zal duidelijk zijn, dat ook deze deskundige, die weinig meer te maken heeft met de uiteindelijk door de gebruiker genomen beslissing, niet aansprakelijk kan worden gesteld. Kortom, rond de aansprakelijkheidsvraag kunnen nog interessante rechtszaken ontstaan.

Hoewel in de kwadranten I en IV de toepasbaarheid en de toepassing met elkaar in overeenstemming zijn, kunnen zich ook in deze kwadranten een aantal van de bovengenoemde problemen voordoen. Bij de verdeling van taken, bevoegdheden en verantwoordelijkheden tussen mens en machine moet hiermee dan ook rekening worden gehouden.

Alleen wanneer volledig is voldaan aan de genoemde voorwaarden voor de toepasbaarheid van kennissystemen als oplosser, kan de taak 'beslissingen nemen' worden overgelaten aan het kennissysteem: dit substitueert dan ook daadwerkelijk de menselijke deskundige. De verantwoordelijkheid voor een correct besluit ligt dan ook bij datzelfde kennissysteem en mag niet worden afgeschoven op de gebruiker, tenzij deze de mogelijkheid heeft om de invoer van gegevens te manipuleren.

Wanneer een bepaald deskundigheidsniveau van de gebruiker noodzakelijk blijft, en dat zal in het leeuwedeel van de gevallen zo zijn, dient de organisatie er zorg voor te dragen, dat de gebruiker ook een dergelijk deskundigheidsniveau kan handhaven. Pas wanneer het deskundigheidsniveau van de gebruiker ook wordt gegarandeerd, kan deze persoon aansprakelijk worden gesteld 
voor zijn beslissingen. Een periodieke toetsing van diens kennis ligt voor de hand. Organisatorische maatregelen om alert te zijn en te blijven op kostbare fouten zijn het invoeren van een scheiding tussen degene die de gegevens invoert en degene die de beslissing neemt of het verplicht stellen van parafering door een menselijke expert van besluiten die genomen zijn op basis van door een kennissysteem getrokken conclusies! In deze gevallen is duidelijk, dat op straffe van foutieve beslissingen de besparing op de loonkosten van menselijke experts door het invoeren van kennissystemen vaak niet zo groot zal zijn als wellicht wordt beoogd.

\section{Conclusies}

Net zoals bij de invoering van andere technieken en systemen in organisaties volstaat de techniek alleen niet om tot de gewenste oplossing te komen. Zoals in het bovenstaande is uiteengezet geldt ook bij kennissystemen, dat voor het succesvol functioneren aandacht besteed moet worden aan de inbedding van de techniek in de organisatie. Afhankelijk van de gebruikswijze van een kennissysteem en de ernst van eventueel gemaakte fouten bij onzorgvuldig gebruik zijn organisatorische aanvullingen op het systeem nodig. Ook kennissystemen zijn niet meer dan een weliswaar vernuftig technisch middel om organisatorische doelen te bereiken. Maar middelen worden gebruikt door mensen, die bij dit gebruik hun eigen doeleinden in plaats die van de organisatie kunnen nastreven. Ook los van de persoonlijke belangen van de gebruiker kan het gebruik van kennissystemen zonder adequate maatregelen leiden tot minder goede in plaats van een betere besluitvorming.

Kennissystemen zijn zonder enige twijfel technieken waarvan in de toekomst veel te verwachten valt. Maar Liebowitz (1988) kan alleen maar met instemming geciteerd worden: 'As executives consider the development and use of expert systems in the company, executives shoud not be fooled by the technology. Expert systems are not the end-all to company problems. [...] If they realise the limitations, as well as the advantages, of expert systems, then the possibility for the executive's overexpectations of expert systems will be minimised'.

\section{Literatuur}

Besselaar, P. van den, 1989, 'Aangrijpingspunten voor technology assessment', in: Proceedings Al Toepassingen '89. SCl: z.p., pp. 503-516.

Doorewaard, H., 1989, 'De vanzelfsprekende macht van het management', Van Gorcum: Assen/Maastricht.

Engelenburg, H., 1990, 'Welkom bij de Hema Verfexpert' in: Automatiseringsgids, jrg. 24, nr. 22, pp. 11-13.

Fox, M.S., 1990, 'Al and Expert Systems; Myths, Legends, and Facts', in: IEEE Expert, vol. 5, nr.1, pp. 8-19.

Goeranzon, B. en Josefson, I. (red.), 1987, 'Knowlege, skills and artificial intelligence', Springer: Berlijn.

Hartman, W., 1990, 'Expertsystemen: toepassingen ontwikkeling - gevolgen voor de organisatie (deel III)', in $M A B$. jrg. 64, nr. 4. pp. 149-152.

Hayes, R., 1989, 'Construction of an International Loan Analysis Expert Systems Prototype', paper RU Limburg ( 9 maart 1989).

Hertz, D., 1988, 'The Expert Executive; Using Al and Expert Systems for Financial Management, Marketing. Production and Strategy', Wiley; New York.

Humpert, B., Teel, B., Najar, E. S., Medsker, L. R. en Cader, M. Z., 1989, 'PEOPL: A Knowledgebased System for the Evaluation of Personnel', in: Expert Systems, vol. 6, nr. 2, pp. 60-72.

Karlsen, T. en Oppen, M., 1985, 'Informationstechnologie im Dienstleistungsbereich', Ed. Sigma: Berlijn.

Keus, H., 1987, 'Aanpak van expertsysteem-projecten', in: Kennissystemen, jrg. 1 nr. 3, pp. 22-27.

Koopman-Iwema, A. M., 1986, 'Automatiseren is reorganiseren; Richtlijnen voor Personeelsmanagement', Kluwer/NVP Deventer.

Lee, D., 1988, 'Expert Decision-Support Systems for Decision Making', in: Journal of Information Technology, jrg. 3, nr. 2, pp. 85-94.

Liebowitz, J., 1988, 'Approaches for Learning about Expert Systems; A Management Introduction', in: Management Decision, vol. 26, nr. 5 pp. 53-57.

Manders, F., 1990a, 'Expertsystemen binnen personeelsmanagement: een verkenning van de mogelijkheden', in: Methoden, technieken en analyses voor Personeelsmanagement, afl. 15, pp. 1-6.2.2 (201-213).

Manders, F., 1990b. 'Expertsystemen: robots van het management?', in: Gids voor Personeelsmanagement, jrg. 69 , nr. 5, pp. 35-38.

Noë, F., 1990, 'Expertsysteem helpt voordeurdeler', in: Automatiseringsgids, jrg. 24, nr. 12, pp. 1-2.

Poel, J. H. R. van de, 1989, 'Contract en beheersing: Een theoretische analyse', in: Maandblad voor Bedrijfsadministratie en Organisatie, jrg. 93, nr. 1107, pp. 150-157. 


\section{MAB}

Polanyi, M., 1962, 'Personal Knowledge: Towards a Post-Critical Philosophy', Routledge \& Kegan Paul: Londen.

Pruijm, R., 1986, 'Expertsystemen in de accountantspraktijk', in: De accountant, jrg. 93, nr. 3, pp. 131-134.

Rose, F., 1988, 'Een gekloonde ingenieur', in: Intermediair, jrg. 24, nr. 44, pp. 17-19.

Ryan, J. L. , 1988, 'Expert Systems in the Future: The Redistribution of Power', in Journal of Systems Management, vol. 39 , nr. 4, pp. 18-21.

Socha, W. J., 1988, ' Problems in Auditing Expert System Development', in: EDPACS, vol. 15, nr. 9, pp. 1-6.

Steenis, W. van, 1990, 'Kennissysteem steeds breder toepasbaar, in: Computable, jrg. 23, nr. 23, pp. 1-6.

Terplan, K., 1987, 'Performance Evaluation and Expert Systems', in: EDP Performance Review, jrg. 15, nr. 9, pp. 1-9.

Wester, P., 1989, 'Kennissystemen en expertsystemen, hoe staat het ermee?', in: Financieel Overheidsmanagement, jrg. 2, nr. 10, pp. 4-7.

Zahedi, F., 1987, 'Artificial Intelligence and the Management Science Practitioner; The Economies of Expert Systems and the Redistribution of MS/OR', in: Interfaces, jrg. 17, nr. 5, pp. $72-81$.

\section{Noot}

1 Vergelijk het begrip 'the tacit component of knowledge'. De filosoof Polanyi (1962) duidt hiermee dat gedeelte van de menselijke kennis aan, waarover men wel beschikt, maar waarvan men zich niet bewust is. Zo zal zelfs een Olympisch zwemkampioen niet of nauwelijks in staat zijn om uit te leggen hoe men moet zwemmen. 